\title{
Pigeon Hawk Catches Dragon-flies
}

\author{
by Maurice G. Street, Nipawin
}

On June 19, 1960, I banded five nestling Pigeon Hawks in a nest on the north border of the Nipawin Golf and Country Club. Playing golf several times a week gave me ample opportunity to keep a fairly regular watch on the nest, and after the young were flying, to observe them.

While on the golf course on the rather warm and humid evening of July 14, I noted great numbers of a species of large dragon-fly flying everywhere. Several times I observed a Pigeon Hawk flying low over the grassy fairways, twisting and turning, much in the manner of a swallow. As the hawk seemed to appear at regular intervals on one particular fairway bordered by tall spruce and pine, I decided to take a closer look, and I was well rewarded by doing so. There I saw the most amazing display of flying I have ever wit- nessed. The Pigeon Hawk, the female parent of the brood I had banded, was catching the large dragonflieis while in full flight. Flying close to the ground, the hawk would catch the dragon-flies by turning on her side and sometimes completely turning over, to attack from below, and snatch them with her feet. It apperared that on a single foray of several hundreds of yards, back and forth, she would catch perhaps five or six dragon-flies, then fly in the direction of a tall group of trees and at the same time uttering the typical Pigeon Hawk call, a rapid "kee-keekee." This call the five young would answer, at the same time flying from the itrees to meet her, and then after a great clamour, they would fly back to the trees. After a few moments, the female would then begin to hunt once more.

\section{A Note on Anting}

by Peter Gregg, La Ronge

On June 27, 1960, in the early evening three Common Grackles were feeding on the ground and exposed rock surfaces near our house at La Ronge. The birds were foraging independently between five and 20 feet apart. One grackle was repeatedly observed to make short runs of perhaps ten quick steps or less, stop and pick up something from the ground or bare rock with his bill. The surprising part of this was whatever it was that the bird picked up, it immediately tucked the object under its wings or rubbed it along the leading edge of its primary feathers. ather times it would tuck the object into the feathers above the base of the tail. The bird was very excited in these actions and its wings flipped about a lot and the bird nearly lost its balance several times. This unusual behaviour lasted several minutes until the grackle was disturbed and flew off.

Although I could not see with my field glasses what the grackle had been picking up, I believe the bird was exhibiting a rather unusual behaviour pattern referred to in literature as "anting." Anting has been observed in many species including the Robin, Starling, Common Grackle, Common Crow, Blackbilled Magpie, and Rose-breasted Grosbeak.

An early note of Audubon's mentioned young turkeys dusting in deserited ants' nests to get rid of "loose scales and prevent ticks and other vermin from attacking them, these insects being unable to bear the odor of the earth in which ants have been."

Another suggested explanation is that the bird is pleasurably stimulated by the crawling of the insects and their acrid secretions or that the birds are ridding the ants of acid before eating them. Still another explanation is that the birds employ the ants to help rid them of their paraisites. This might be accomplished either by the anits carrying off some of the lice or mites, etc., or more likely, by the beneficial effect of the formic acid secreted by the ants.

Tame birds have been observed to dress their feathers with lemon juice or vinegar, supporting the idea that the birds are seeking an acidic dressing when they exhibit "anting behaviour." 